\title{
A Critical Discourse Analysis on the Instagram Account of @filosofi_jawa Based on Van Dijk Model
}

\author{
Meirika Iin Setyawati* \\ Javanese Language Education of Graduate School \\ Universitas Negeri Yogyakarta \\ Yogyakarta, Indonesia \\ meirikaiin@gmail.com
}

\author{
Mulyana \\ Javanese Language Education of Graduate School \\ Universitas Negeri Yogyakarta \\ Yogyakarta, Indonesia \\ mul_mj@yahoo.com
}

\begin{abstract}
This research discusses about critical discourse analysis based on Van Dijk theory on the instagram account of @filosofi_jawa. It aims to explain the theme and moral lessons embedded in the discourse on the instagram account of @filosofi_jawa. This was a descriptive qualitative research. The data source in this research was the instagram account of @ filosofi_jawa. The technique of data collection was done by documenting the screenshots of the images containing the discourse on the @filosofi_jawa instagram account. Furthermore, the discourse was analyzed using the critical discourse analysis method with content analysis model based on Van Dijk theory. Critical discourse analysis method was carried out to explain the hidden purpose in the discourse, while content analysis aims to explain the content of the discourse. The validity phase of the data in this research was done by source triangulation technique. The results of this research show that there are three themes in the discourse on the @filosofi_jawa instagram account from January to May 2018 which are social, religious and love themes. Moral values which can be concluded from social themes include the order to always do good deeds, to be a patient person, to interact well with others, and to take care of the beauty of the world. There are two moral values which can be taken from religious themes. They are the orders to repent and to give alms in order. Meanwhile, moral value which can be taken from the theme of romance is that if one wants to get a compatible life companion, he should also make efforts to have deserving personalities too.
\end{abstract}

Keywords-- critical discourse analysis, discourse theme, moral lesson

\section{INTRODUCTION}

Discourse is a form of verbal communication. As one of the language elements, discourse is the most complete and complex element. The supporting units of the language include phonemes, morphemes, words, phrases, clauses, sentences, and paragraphs to full essay (Mulyana, 2005). In terms of form, discourse can be divided into two, written and verbal discourse. As explained by Payuyasa (2017), discourse can be presented with various intentions by the speaker to the interlocutor. Through discourse, speakers can convey various forms of opinions or thoughts verbally and in written form.

The word wacana which means discourse is originated from Sanskrit wac / wak / vak, meaning 'to say', (Douglas in Mulyana, 2005). Suciartini (2017) conveys that in the critical discourse analysis (CDA), it is necessary to study the context of a discourse such as setting, situation, event, and condition. Discourse in this case is understood, produced, and analyzed in certain contexts. CDA also examines the context of communication; who communicates with whom and why; in what kind of audience and in what situation; through what medium; how the different types of communication develops, and how the differences are created by each party. Language in this case is understood in context as a whole.

The method used in this research was the critical discourse analysis method of Teun A. Van Dijk. Van Dijk divides this discourse element into three levels, macro structure, superstructure, and micro structure. However, even though they consist of various elements, all are interconnected, related, and support each other. Based on this analysis, it can be understood how to determine the structure of a text.

Macro structure is a global or general meaning of a text which can be observed by looking at the topic or theme emphasized in a text. Superstructure is the structure of discourse that is related to the framework of a text, how the parts are arranged as a whole. Micro structure is the meaning of discourse that can be observed by small parts of a text such as words, sentences, propositions, clauses, and images (Van Dijk in Eriyanto, 2009).

Of the three elements presented by van Dijk, this research limited its element to the macro structure. Therefore, the observation only focuses on the theme of discourse. Teun A. Van Dijk conducted an analysis using an approach concerning social cognition. The theme in the discourse was analyzed by relating to events or social events. Therefore, the meaning or purpose of the discourse text could be analyzed.

Discourse is often intended to be consumed by many people. Therefore, social media is one of the means to convey information in the form of discourse to the public. Social media which cannot be separated from the society now is instagram. Instagram is an application that is widely used by smartphone users. In this application, users can share photos or videos with other users who mutually follow. Other than that, users can also take photos or videos shared by other users. Mauludy (2018) states that instagram is one of the media that serves to display photos 
where someone can download them using the internet connection, so other users can receive and view these photos in real time.

The instagram account of @ filosofi_jawa is an account managed by someone (with an anonymous profile) who resides in the Special Region of Yogyakarta. This account has 170,000 followers. The posts which are uploaded on the instagram page are in the form of text and photos, which embody discourse. The discourse conveyed by this account is in the form of written discourse which uses Javanese as the content language. In this @filosofi_jawa account, there are many discourses on philosophical values for Javanese people. These moral values can be a moral lesson or message for Javanese society in life to become people with good characters, people with culture, and people who maintain good relationships with society and God.

As discourse containing philosophical value for the society, a critical approach is needed to find out the meaning of the discourse shared by the @filosofi_jawa account. The approach is a critical discourse analysis (CDA) conducted in the discourse on the @filosofi_jawa instagram account. The purpose of this approach is to explain the hidden meaning in the discourses conveyed by the author of the account. It is done to help the readers to take moral lessons or messages from the discourse on the @ filosofi_jawa instagram account and the messages can be implemented in everyday life.

In the current era of globalization, millennial generation is considered to be likely to experience a character degradation of the social surrounding. In addition to the positive effects, the technological sophistication also poses negative impacts on its users, especially the younger generation. One of the impacts is that the younger generation or so-called millennial generation tends to be individualistic and ignorant of the social surrounding. Therefore, this research is expected to play a role in overcoming the moral decline of the younger generation using the nobility of Indonesian culture especially Javanese culture.

\section{RESEARCH METHOD}

This research was a descriptive qualitative research. Jane Richie in Moleong (2014) explains that qualitative research is an attempt to present the social world, and its perspective in the world in terms of concepts, behaviors, perceptions, and issues about the people investigated. The data were obtained by analyzing the discourse on the @ filosofi_jawa instagram account based on the Teun Van Dijk model.

The object of the study analyzed in this research was the discourse on the @filosofi_jawa instagram account. The data obtained were descriptive data in the form of Javanese language discourse. This theme was chosen because according to the researchers, this instagram account presents the Javanese language discourse has not been examined. Therefore, the researchers aim to analyze it in order to promote Javanese values to a wider society.

The research unit conducted by the researchers was to focus on the discourse shared by the @filosofi_jawa instagram account related to the phenomena experienced by the millennial generation currently. The discourse posts analyzed were also selected in a sequential period in order to retrieve the data, because there were too many posts shared by the account besides Javanese language discourse, such as promotions, public information, and advertisements.

This research had two type of data, primary data and secondary data. Primary data were in the form of data sources obtained from the discourse posts shared by the @ filosofi_jawa instagram account from January to May 2018. The data collection technique was done by documenting the screenshots of images containing discourse on the @filosofi_jawa instagram account. While secondary data were data sources used by researchers as supporting data for analysis in the research, such as journals, papers, books, and articles related to research material.

The object analyzed were in the form of 24 discourses obtained from the @filosofi_jawa instagram account from January to May 2018. After the discourses were collected, they were analyzed using the critical discourse analysis method based on Van Dijk's content analysis model. It aimed to explain the content of the discourse, while the critical discourse analysis explained the hidden intentions in the discourse.

The validity phase of the data in this research was done by source triangulation technique. In determining the validity of the research results, the researchers conducted an observation on person's circumstances and perspectives, and then comparing them with various opinions and views of the general society, especially Javanese people from various social background, ranging from commoners to officials, low to high educated society, and so forth.

\section{RESULT OF THE STUDY AND DISCUSSION}

There were 24 discourses on the @filosofi_jawa instagram account from January to May 2018. The discourses consist of social, religious, and romance themes. Most of the discourses are included in the social themes with 21 discourses. There are only two with religious themes and one with romance theme.

Moral values are found in the discourse according to the theme and content of the discourse. The similar and almost similar messages are well distributed making them to be more general. The general moral message is conveyed to the reader so that the readers are able to live well.

The general moral lessons conveyed through the discourse include an order to always be a good person, be aware in living, be a person who is not easily hurt by others, be a person who gets along well with others and so forth. The religion-loaded discourse presents a message to almsgiving in order to have a blessed life. As for the discourse with the theme of romance one is encouraged to remain patient in waiting for the life companion.

\section{a. Social Theme}

The discourse with social themes is a discourse about life advices in the society and the interaction of human 
relationships among people. The discourse with social themes includes.

\section{- Aja leren dadi wong apik}

The discourse has a message to its readers that as long as we live we must never stop being a good person. "Wong apik" is a person who is able to control himself not to hurt others both physically and spiritually. Even if we are hurt by other people, we should never take revenge to that person.

"Aja leren dadi wong apik" is an order not to stop being a good person. It is like what Hudi (2017) says that at the highest level of moral reasoning, it also involves the understanding of some classical moral principles, one of which is to do good deeds.

- Urip iku mung sawang sinawang, mula aja mung nyawang sing kesawang

Based on the discourse above, the social message that we can take is that what we see from someone's life is just what it seems to be. That is not the truth. It's just a fact that every human being has their own camouflage way to cover up the problems in their life. Therefore, as human being, it is better that we do not see what our mere eyes see but trying to see from the other side which sometimes is hidden.

"Sawang sinawang" literally means seeing each other. "Urip iku sawang sinawang" means that in life, we can not only see what appears from outside. This means that we cannot see what is actually happening in other people's lives. What seems good in our perspective is not necessarily good for those who experience it. Seeing what other people have sometimes creates jealousy when we do not know how other people are actually struggling for to afford it. Being envy and jealous are the traits that we must avoid because they will only make life uneasy and cause us to always think of ways to make the same with or surpass others.

As humans who live in the middle of society, we should always be grateful for what we have. Therefore, "mula aja mung nyawang sing kesawang" which means do not just see other people's lives from what appear to be. We must be legawa, an attitude to be sincerely accepting, and must be able to understand the other side of others' life, which should not be necessarily shown to others.

\section{- Datan serik lamun ketaman, datan susah lamun kelangan}

Based on this discourse, we are taught to have a sincere attitude in dealing with life problems in this world. "Serik" is a Javanese word that means resentment. "Susah" is a feeling which arises when something unpleasant happens. Both of these traits are indeed very common to be felt by every human being when they deal with problems such as "ketaman" and "kelangan".

Therefore, if this discourse is translated, it says we do not easily complain when dealing with problems, do not be sad when losing something. Even though everyone feels pain and hurt, but we are not allowed to have excessive feeling as it is not good. When we are hit by problems, we should be graceful and sincere in accepting them. Life does not always go as what we expected, there must be challenges and problems we need to face. We should believe that after encountering hardship, something better entails. Similarly, when we lose something, we must sincerely let it go because later it will be definitely replaced. Problems and life tests are His will. For that reason, we can take the lessons to make us more mature in thinking. In addition, it can be beneficial to improve ourselves to be better in life.

- The next social value found in the discourse by @ filosofi_jawa is that as humans we must be patient in dealing with anything.

The discourses related to the above theme are

- Tanggal tuwa, diseneni mara tuwo, tetep kudu legawa;

- Dadio wong sing sabar Atine digae amba uripe ora perlu nggresula;

- Ati kudu bungah aja digawe susah;

- Pokoke prinsipe sederhana iku mewah;

- Nek ono sing ngunekne kowe ki Asu, ojo kesusu nesunesu. Coba dicek, kowe duwe buntut ora. Nek ora, berarti prelu ana sing perlu dimasalahke.

The main idea of the discourses above is that we must have patience in dealing with the problems which befall us in life. These problems can be both family problems and the problems with other people around us. In addition, we also must always be aware in determining the steps in our life. As stated in the discourse Eling lan waspada, if we can adopt this principle of life, we are more likely to be able to deal with all the temptations in our life. It is for the reason that basically human will always be tempted, depending on how we deal with it. If we are able to avoid it, then we will be safe in the world and the hereafter.

- Moral lessons in socializing with people

Conveyed in the discourse by @ filosofi_jawa as Urip kurang srawung, uripmu krasa suwung, Desa mawa cara, negara mawa tata, Aja bedakake marang sapadha-padha, Sekolahe dhuwur, tapi kok tumindake ngawur?, Ngluruk tanpa bala, menang tanpa ngasorake.

From these discourses, the author's message is that we feel lonely if we do not socialize with others. However, in interacting with others, we should not discriminate people based on religion, ethnicity, race and other because before God, we are equal and the difference lies only on our deeds. Particularly, if the person can pursue higher education but he or she is not well behaved, do not be arrogant person because of your power and intelligence, or do not feel superior that you undermine others. Therefore, these traits must be avoided.

- For the social theme, the message is that we have to make efforts to fulfil our needs.

Making an effort is said to be Ora obah ora mamah which means that we can meet the needs of life by working hard. Our intention will be the source of strength within us as stated in the discourse Niat iku sumbere kuat.

The next discourse is Memayu hayuning bawana, ambrasta durangkara, Alam iki Sejatining guru. The point is that nature can be our teacher and our experience in 
order to live better. We have to take care of the beauty of the world by avoiding destructive actions, because nature can be a teacher of our life.

\section{b. Religious Theme}

The discourse with religious theme is a discourse about human relations with the Creator, God. On the instagram account of @filosofi_jawa, there are two religion-themed discourses which are Mending taubat timbang sambat sing ora manfaat and Sedekah sumber barokah.

\section{- Mending taubat timbang sambat sing ora manfaat}

The moral message in the discourse above is that we should always ask for forgiveness from Allah SWT for the deeds we have done. "Taubat" is the intention of a human beings to Allah SWT not to repeat the sins they have done. As faithful and God-fearing human beings, we surely understand the deeds that we should carry out and avoid. However, there are still people who deliberately act not to obey what the religion says. In addition, there are also humans who unintentionally commit act that we consider to be good but in fact, it is forbidden by religion. This certainly will be harmful to our life. This is in line with what Winarni (2017) says that many people who have repented, their life is more peaceful because they know Allah SWT and they let themselves to be better.

Meanwhile, the impact of actions we committed can be immediately experienced such as feeling uneasy and not peaceful because of too many problems we are dealing with. If someone always deals with problems, as a common human being will definitely "sambat" or complaining about what happened to him or her. Therefore, on the account of @filosofi_jawa, there is a discourse mending taubat timbang sambat sing ora manfaat which means it is better to repent than to complain because complaining will not be useful and will not solve any problems.

Instead of complaining about something, it is better to repent, get closer to Allah AWT and introspect ourselves on the actions we have committed so far. If we only complain, the problem will not be solved. However, if we repent asking for help from Allah SWT, surely we will find a way to solve the problems.

\section{- Sedekah sumber barokah}

The moral message that can be taken from the discourse is an order to do almsgiving to have a blessed life. In Islam perspective, it is said: if someone dies, his or her deeds come to end except three things: ceaseless alms, useful knowledge, virtuous children's prayers (HR Muslim in Sapitri, 2014). Every human being would like to have blessing in their life. If they are blessed, it will certainly bring happiness to their life. One of ways to get a blessed life is by doing almsgiving.

Alms is an act of giving to others. Our possession in this world is other people's rights too. We can give to others not merely in the material form. When we do not have enough material assistance to share, we can still help those in need with our energy without expecting anything in return. One of the benefits of almsgiving is that we can help ease the burden on other people. Therefore, our life will be blessed when we do almsgiving. By giving alms to those who are entitled, then God will give blessings in our life. In addition, God will also ease our business.

\section{c. Romance Theme}

The discourse of romance theme is a discourse discusses human love with the opposite sex. There was only one discourse on romance theme on the instagram account of @filosofi_jawa from January to May 2018 which is Wong ayu pirang-pirang sing gelem karo kowe arang-arang.

What defines what a beautiful person looks like is very relative. Some people see that a beautiful woman is only seen from the physical appearance, but there are some people who believe that a beautiful woman is a woman with good personality. It is common if a man is to choose beautiful woman to be his life partner. However, the problem is, whether the woman wants to be her partner. As conveyed from the discourse above "sing gelem karo kowe arang-arang" which means that not all beautiful women want to accept them. For this reason, the moral message taken is, a man cannot underestimate a woman, because she does not necessarily want to be with him. Therefore, if he wants to get a beautiful and kind life companion, as a man he must also make efforts in order to deserve a kind person.

\section{CONCLUSION}

Based on the research and analysis conducted, it can be concluded that there are themes and moral lessons from the discourses on the @filosofi_jawa instagram account. The result of this research is that there are three themes in the discourses of @filosofi_jawa instagram account from January to May 2018, social, religious and romance themes. Of the three themes, social theme is the highest number with 21 discourses. There is only one discourse with romance theme.

Based on the number of themes analyzed, it can be concluded that the author of the instagram account of @ filosofi_jawa aims to send more messages to the reader about human's life as social beings. Moral values that can be drawn from social themes include the orders to always do good deeds, to be patient, to always make efforts to make yields, to establish good interactions with other people and to take care of the nature.

Furthermore, there are two moral lessons taken from religious themes, orders to repent and to do almsgiving to create peace and blessings in life. Lastly, in discourses with romance theme, the moral message is that if we want to have a good life companion, we should make efforts to deserve a kind person.

The moral message in each discourse on the @ filosofi_jawa instagram account is generally conveyed. The moral values embedded are addressed to readers or users of the instagram application, especially the followers of @filosofi_jawa. The readers can implement the moral values in the discourse into everyday life, both for their relationship with the Creator and with others. 


\section{REFERENCES}

Eriyanto. (2008). Analisis wacana: pengantar analisis teks media. Yogyakarta: LKIS.

Hudi, I. (2017). Pengaruh pengetahuan moral terhadap perilaku moral pada siswa smp negeri kota pekan baru berdasarkan pendidikan orang tua. Community Moral Journal, 2(1), 330-44. Retrieved from http://ejournal.unikama.ac.id/index.php/JMK/article/download/1698/ $1435 /$

Mauludy, M. N. (2018). Analisis wacana persausif pada akun instagram @ gerakannikahmuda. (Undergraduate Thesis, UIN Syarif Hidayatullah, Jakarta). Retrieved from http://repository.uinjkt.ac.id/dspace/bitstream/123456789/41697/1/M UHAMMAD\%20NAUFAL\%20MAULUDY-FDK.pdf

Moleong, L. J. (2014). Metode penelitian kualitatif. Bandung: PT Remaja Rosdakarya.

Mulyana. (2005). Kajian wacana. Yogyakarta: Tiara Wacana.

Payuyasa, I.N. (2017). Analisis wacana kritis model van dijk dalam program acara mata najwa di metro tv. Segara widya research
Journal, $\quad 5, \quad$ 14-24. $\quad$ Retrieved from http://digilib.mercubuana.ac.id/manager/t!@file_artikel_abstrak/Isi_ Artikel_174855971552.pdf

Sapitri, A. (2014). analisis wacana citra perempuan pada rubrik ada apa dengan hari ibu di majalah daqu. (Undergraduate Thesis, UIN Syarif Hidayatullah, Jakarta). Retrieved from http://repository.uinjkt.ac.id/dspace/bitstream/123456789/27049/1/A NNA\%20SAPITRI-FDK.pdf

Suciartini, N. N. A. (2007). Analisis wacana kritis "semua karena ahok" program mata najwa metro tv. Aksara Journal, 29(2), 267-282. Retrieved from

http://aksara.kemdikbud.go.id/jurnal/index.php/aksara/article/view/54

Winarni. (2017). Analisis wacana taubat dalam novel baikt surau karya wahyu. (Undergraduate Thesis, UIN Syarif Hidayatullah, Jakarta). Retrieved from

http://repository.uinjkt.ac.id/dspace/bitstream/123456789/36854/1/W INARNI\%20\%20FDK.pdf 